\title{
Optimization of Enzymatic Decolourization of Amido black by Laccase from Rigidoporus ulmarius using Response Surface Methodology
}

\author{
Poornima $\mathrm{R}^{1}$, Sneha $\mathrm{U}^{2}$, Sridhar $\mathrm{S}^{3}$ \\ ${ }^{1,2} \& 3$ Department of biotechnology, Jeppiaar Engineering college, Chennai 600119, Tamil Nadu, India.
}

\begin{abstract}
In this study laccase mediated decolourization of Amido black, an azo dye was attempted. Laccase was extracted from the solid state fermentation of the white rot fungi Rigidoporus ulmarius on rice bran (50\%). The enzyme activity was assayed using guaiacol as substrate and was found to be $0.0145 \mathrm{U} / \mathrm{ml}$. The crude enzyme extract was employed for decolourization experiments. Optimization of the effect of contributing variables; $\mathrm{pH}$, temperature, dye concentration and enzyme volume on decolourization was primarily analysed using OFAT (One Factor At a Time) approach. The optimum operating conditions for maximum decolourization were further statistically optimized by applying the Response surface methodology using Box-Behnken approach. A four factor three level Box-Behnken design generating 29 experimental runs was performed. A quadratic model was fitted and was analyzed using ANOVA at the 95\% confidence interval. The determination coefficient $R^{2}$ was found to be 0.9616 indicating the significant fit of the model. The optimum operating conditions predicted by the model was found to be at constant incubation time of $24 \mathrm{hrs}, \mathrm{pH}$ of 4; temperature of $30^{\circ} \mathrm{C}$; dye concentration of $150 \mathrm{mg} / \mathrm{l}$ and enzyme volume of $1.25 \mathrm{ml}$ producing $83.39 \%$ decolourization which was in good agreement with that of the predicted value, $83.24 \%$.
\end{abstract}

Key words: Amido black, Box-Behnken design, Laccase, Rigidoporus ulmarius, solid state fermentation.

\section{Introduction}

Various classes of dyes which are stable to light, chemicals and microbial degradation are used by textile, cosmetic, plastic and printing industries [1]. About $60 \%$ of these dyes are azo dyes which are recalcitrant pollutants causing serious environmental and health concerns [2,3]. They are toxic, mutagenic and carcinogenic in nature and in addition some causes allergy, skin irritation in humans [4,5]. Amido black is an azo dye; the carcinogenic and mutagenic effects are not well studied.

Large amount of effluents from textile processing industries are liberated with varied composition, various physical/ chemical methods have been used for the removal of dyes from wastewaters [6]. Physiochemical methods of dye removal are effective only if the effluent volume is small and sometimes the degradation products are toxic [7].

Enzymatic decolourization is an inexpensive eco-friendly alternative to the conventional treatment methods as they can operate over a wide range [6]. Several enzymes (peroxidases, manganese peroxidases, lignin peroxidases, laccases, microperoxidase-11, polyphenol oxidases and azoreductases) have been evaluated for their potential in decolourization and degradation of dyes.

Laccase, copper containing oxidases are mainly produced by white rot basidomycetes and other fungal [8] and bacterial strains and also some plants have been used in various biotechnological and environmental processes. Lack of substrate specificity enabled laccase as an enzyme able to oxidize wide range of chemical compounds such as diphenols, polyphenols, diamines, aromatic amines, benzenethiols, and substituted phenols [9] as well as different groups of colored pollutants. Decolourization of a wide range of synthetic and textile dyes using laccases from basidomycetes has been investigated in recent years.

In this study laccase from a white rot fungi Rigidoporus ulmarius was extracted and utilized for the decolourization of an azo dye, amido black. The decolourization experiments were optimized further using Response surface methodology to obtain the optimum operating conditions for maximum decolourization.

\section{Materials And Methods}

\section{Materials and reagents}

Amido black ( $\lambda$ max-617nm) and all other chemicals of analytical grade was purchased from HI-Media (India). Rigidoporus ulmarius MTCC 1095 was procured from IMTECH, Chandigarh, India. Stock standard solution of the dye $(1 \mathrm{~g} / \mathrm{L})$ was prepared using double distilled water. This solution was diluted to appropriate concentrations before use $(100 \mathrm{mg} / \mathrm{L}-300 \mathrm{mg} / \mathrm{L})$. 


\section{Enzyme production and recovery}

Solid state fermentation of Rigidoporus ulmarius on rice bran was carried out for enzyme production. $10 \mathrm{~g}$ ground, oven-dried rice bran was sterilized by autoclaving at $121^{\circ} \mathrm{C}$ for $15 \mathrm{mins}$ and inoculated with five $5 \mathrm{~mm}$ plugs of the fungus. The setup was incubated for 30 days at $30^{\circ} \mathrm{C}$ in static condition to reach growth confluence maintaining the moisture content at $50 \%$ with addition of sterile distilled water supplemented with $(0.01 \% \mathrm{w} / \mathrm{v})$ peptone every $3^{\text {rd }}$ day.

The extracellular enzyme was extracted using $50 \mathrm{mM}$ sodium acetate buffer $\mathrm{pH} 5.5$ supplemented with $1 \%$ tween 20 at $25^{\circ} \mathrm{C}$ in static condition. The extraction was carried out in two cycles, medium was incubated with i) $75 \mathrm{ml}$ buffer for $5 \mathrm{hrs}$ and filtered with constant stirring ii) $110 \mathrm{ml}$ of buffer for $3 \mathrm{hrs}$ and filtered. The filtrates were centrifuged at 5000rpm for $15 \mathrm{mins}$. The supernatants collected served as the source of crude enzyme [10].

Enzyme assay (laccase) was carried out using guaiacol as substrate [11-13]. The change in absorbance was monitored at 530nm using UV-Vis spectrophotometer. Enzyme activity was calculated using the following formula (1).

Volume activity $(\mathrm{U} / \mathrm{ml})=\Delta \mathrm{A} 530 / \min \mathrm{x} 4 \mathrm{x}$ Vt $\mathrm{x}$ dilution factor

Where,

$$
\text { e } \mathrm{x} \text { Vs }
$$

$\mathrm{Vt}=$ final volume of reaction mixture $(\mathrm{ml})=5.00$

$\mathrm{Vs}=$ sample volume $(\mathrm{ml})=1$

$\mathrm{e}=$ extinction co-efficient of guaiacol $=6,740 / \mathrm{M} / \mathrm{cm}$

$4=$ derived from unit definition \& principle

Enzyme activity is measured in $\mathrm{U} / \mathrm{ml}$ which is defined as the amount of enzyme catalyzing the production of one micromole of colored product per min per ml [14].

\section{Decolourization studies}

The effect of contributing process parameters on decolourization were analyzed using OFAT (One Factor At a Time) approach. The factors include $\mathrm{pH}$, temperature, dye concentration and enzyme volume. The factors were varied one at a time keeping others constant according to the variable analyzed. The absorbance at the absorption maxima at initial hour and after 24 and $48 \mathrm{hrs}$ of incubation was recorded and the residual dye concentration was represented in terms of percentage $[15,16]$. The decolourization of dye, expressed as dye decolourization $(\%)$, was calculated according to the formula:

Decolourization $(\%)=[(\mathrm{Ci}-\mathrm{Ct}) / \mathrm{Ci}] \times 100$

Where

$\mathrm{Ci}$ : initial concentration of the dye and

$\mathrm{Ct}$ : dye concentration along the time [17].

The effect of $\mathrm{pH}$ on decolourization was studied by varying the medium $\mathrm{pH}$ from 3-9 at room temperature with initial dye concentration of $100 \mathrm{mg} / \mathrm{l}$. The temperature in the range of $30^{\circ} \mathrm{C}-50^{\circ} \mathrm{C}$ was varied at the optimum $\mathrm{pH}$ and initial dye concentration. The dye concentration was increased from $100 \mathrm{mg} / \mathrm{l}$ to $300 \mathrm{mg} / \mathrm{l}$ in multiples of $50 \mathrm{mg} / \mathrm{l}$ at the optimum $\mathrm{pH}$ and temperature. The enzyme volume was varied from $0.25 \mathrm{ml}$ to $1 \mathrm{ml}$ and the effect on decolourization at the optimum $\mathrm{pH}$, temperature and initial dye concentration was recorded. The experiment was carried out in triplicate.

\section{Statistical optimization of process variables}

Response surface methodology for the statistical optimization of the influencing process variables was adopted. The influencing parameters considered for optimization includes: $\mathrm{pH}\left(\mathrm{X}_{1}\right)$, Temperature $\left(\mathrm{X}_{2}\right)$, dye concentration $\left(\mathrm{X}_{3}\right)$ and enzyme volume $\left(\mathrm{X}_{4}\right)$. A four factor three level Box-Behnken design was designed using the software. The 29 run experimental design was performed and the response was calculated in terms of percentage decolourization. A best fit quadratic model was suggested and was further analyzed using ANOVA at $95 \%$ confidence interval, the fit quality was evaluated by coefficient of determination $\mathrm{R}^{2}$ and comparing it with the predicted $\mathrm{R}^{2}$. The validity of the model was verified by performing the confirmatory trials which produced response which were in good agreement with the predicted response. 
Enzyme assay

\section{Results And Discussion}

The enzyme extracted from solid state fermentation of the fungus was assayed for its activity using guaiacol as substrate in both crude extracts. The enzyme activity was found to remain almost constant in both extractions. The crude enzyme from first extraction cycle showed an activity of $0.0129 \mathrm{U} / \mathrm{ml}$ and $0.0145 \mathrm{U} / \mathrm{ml}$ in the second extraction cycle.

\section{Decolurization using crude enzyme}

The enzyme based decolourization of Amido black was carried out. The influencing process parameters; $\mathrm{pH}$, temperature, dye concentration and enzyme volume were optimized preliminarily using OFAT. The decolourization was studied after 24 and $48 \mathrm{hrs}$ of incubation. From the results obtained it was found that increase in incubation time did not cause significant change in decolourization. The dye was maximally decolorized to about $83 \%$ in OFAT. The optimum $\mathrm{pH}$ for decolourization was at the enzyme optimum pH 5 . The optimum temperature for decolourization was $30^{\circ} \mathrm{C}$. The decolourization did not vary significantly at the enzyme optimum temperature of $35^{\circ} \mathrm{C}$. The decolourization at different dye concentration did not vary significantly; however maximum decolourization was observed at $150 \mathrm{mg} / \mathrm{l}$ concentration. The optimum enzyme volume was found to be $1 \mathrm{ml}$, though only slight difference was seen in the decolourization produced with $0.75 \mathrm{ml}$ of the enzyme. Fig $1(\mathrm{a}), 1(\mathrm{~b}), 1(\mathrm{c})$ and $1(\mathrm{~d})$ show the effect of $\mathrm{pH}$, temperature, dye concentration and enzyme volume on decolourization of Amido black by the enzyme.

1 (a) Effect of $\mathrm{pH}$ on decolourization of Amido black using enzyme

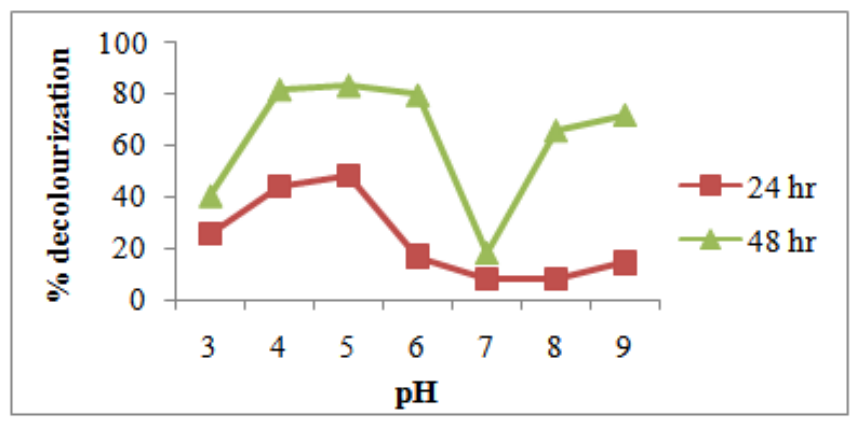

1 (b) Effect of temperature on decolourization of Amido black using enzyme

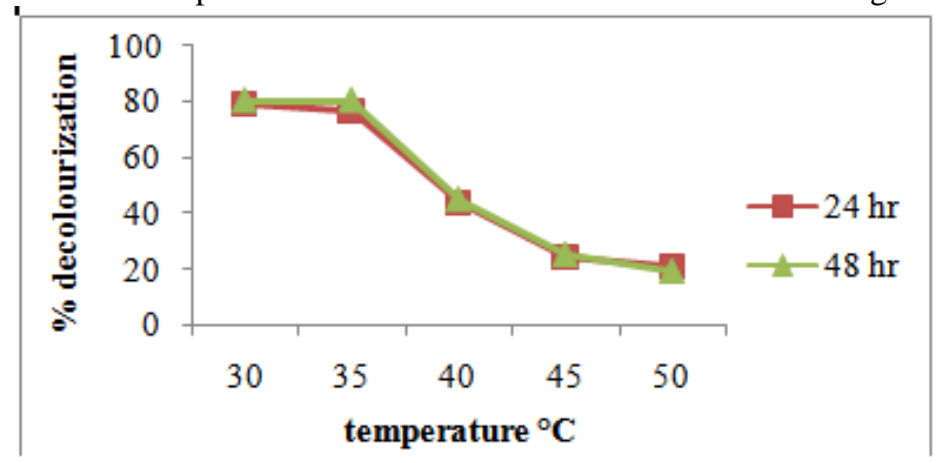

1 (c) Effect of dye concentration on Amido black decolourization using enzyme

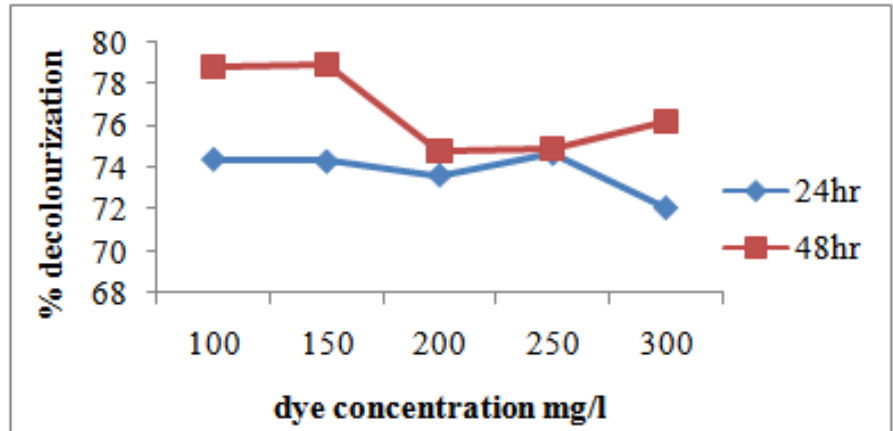


1 (d) Effect of enzyme volume on Amido black decolourization

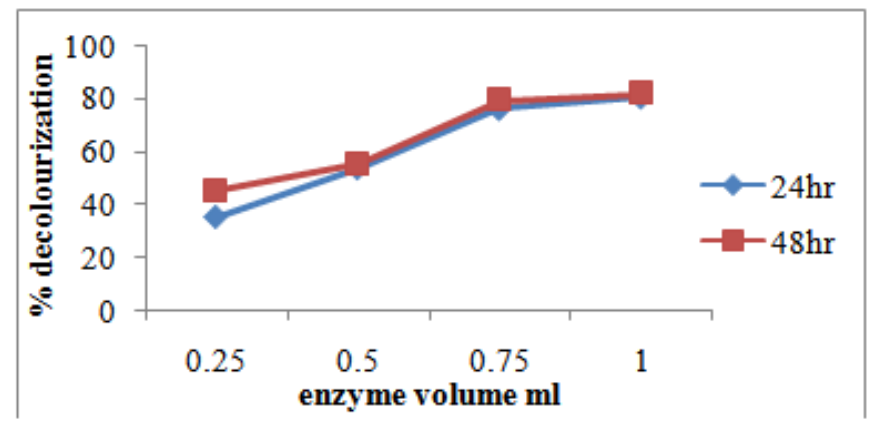

\section{Statistical Optimization of Amido black decolourization by enzyme}

The statistical optimization of the process variables was carried out to obtain the optimum operating conditions for decolourization producing maximum possible decolourization with precision and reproducibility. The response was fitted in terms of \% decolourization and a second order quadratic model with effect of linear, quadratic and interaction terms on response was suggested by the software as the best fit. The test of significance of the model, individual coefficients and test for lack of fit was performed.

Table 1 represents the design matrix with the experimental and predicted value for Amido black decolourization by enzyme. The model was significant showing a Prob $>\mathrm{F}$ value of $<0.0001$. The linear factors of $X_{1}, X_{2}$ and $X_{4}$; quadratic factor of $X_{1}$ and interaction terms $X_{1} X_{2}, X_{1} X_{4}$ were found to be significant at $95 \%$ confidence interval indicating that the model terms are a limiting factor for decolourization. The determination coefficient $\mathrm{R}^{2}$ was found to be $96.16 \%$ and adjusted $\mathrm{R}^{2}$ was $92.32 \%$ indicating the high significance of the model. The multiple correlation coefficient, $\mathrm{R}$ and the determination coefficient $\mathrm{R}^{2}$ are the measure of correlation for estimation of the regression equation. The closer the value of $\mathrm{R}$ to 1 , the better the prediction of the model is [18]. A higher determination coefficient indicates higher degree of correlation between the experimental and predicted values and it is also a measure of fit of the model. $F$ value for the model was found to be 25.05 . The $\mathrm{F}$ value is a statistically valid measure of how well the factors describe the variation in the data about its mean. The greater the $\mathrm{F}$ value is from unity, the more certain it is that the factors explain adequately the variation in the data about its mean, and the estimated factor effects are real. From these observations, it could be concluded that interactive effects are important for true optimization rather than the OFAT method [19]. The insignificant lack of fit explains that the model is adequate to describe the observed data. The lack of fit value was insignificant and was found to be 0.3714. Table 2 shows the ANOVA for Amido black decolourization by enzyme. Equation (3) represents the second order polynomial regression predicted equation for amido black decolourization by enzyme.

$\mathrm{Y}=69.846-4.06 \mathrm{X} 1-1.57 \mathrm{X} 2+0.1675 \mathrm{X} 3+5.04 \mathrm{X} 4+2.18 \mathrm{X} 1 \mathrm{X} 2+1.05 \mathrm{X} 1 \mathrm{X} 3-1.945 \mathrm{X} 1 \mathrm{X} 4-0.22 \mathrm{X} 2 \mathrm{X} 3-0.46$ $\mathrm{X} 2 \mathrm{X} 4-0.14 \mathrm{X} 3 \mathrm{X} 4+2.79 \mathrm{X} 12+0.93 \mathrm{X} 22-0.411 \mathrm{X} 32-0.438 \mathrm{X} 42-----(3)$

The optimum operating conditions for enzyme based decolourization was found to be at constant incubation time of $24 \mathrm{hrs}$, $\mathrm{pH}$ of 4 ; temperature of $30^{\circ} \mathrm{C}$; dye concentration of $150 \mathrm{mg} / \mathrm{l}$ and enzyme volume of $1.25 \mathrm{ml}$ producing $83.39 \%$ decolourization which was in good agreement with that of the predicted value, 83.24\%.

The 3D and 2D contour plots are graphical representation of the regression equation which aims to showcase the optimum variable interactions such that the response is maximal. Each contour curve represents an infinite number of combinations of two test variables. A circular contour plot of response surfaces suggest that the interaction is negligible between the corresponding variables, while an elliptical or saddle contour plot indicates significance in the interactions between the corresponding variables [20]. Fig 2 (a) and (b) represents the $2 \mathrm{D}$ contour plots showing significant two variable interactions for Amido black decolourization by enzyme. 
Table 1 Design matrix for Amido black decolourization by enzyme

\begin{tabular}{|c|c|c|c|c|c|c|}
\hline \multirow{2}{*}{ Std } & \multirow{2}{*}{$\begin{array}{l}\mathrm{pH} \\
\mathrm{X}_{1}\end{array}$} & \multirow{2}{*}{$\begin{array}{c}\text { Temperature } \\
\left({ }^{\circ} \mathrm{C}\right) \\
\mathrm{X}_{2}\end{array}$} & \multirow{2}{*}{$\begin{array}{c}\text { Dye } \\
\text { concentration } \\
(\mathrm{mg} / \mathrm{l}) \\
\mathrm{X}_{3}\end{array}$} & \multirow{2}{*}{$\begin{array}{c}\text { Enzyme } \\
\text { volume } \\
(\mathrm{ml}) \\
\mathrm{X}_{4}\end{array}$} & \multicolumn{2}{|c|}{$\begin{array}{c}\text { Response } \\
(\%) \text { Decolourization }\end{array}$} \\
\hline & & & & & Experimental & Predicted \\
\hline 1 & 4 & 25 & 150 & 1 & 81.37 & 81.39 \\
\hline 2 & 6 & 25 & 150 & 1 & 70.17 & 68.89 \\
\hline 3 & 4 & 35 & 150 & 1 & 72.73 & 73.87 \\
\hline 4 & 6 & 35 & 150 & 1 & 70.28 & 70.12 \\
\hline 5 & 5 & 30 & 100 & 0.75 & 64.17 & 63.64 \\
\hline 6 & 5 & 30 & 200 & 0.75 & 64 & 64.26 \\
\hline 7 & 5 & 30 & 100 & 1.25 & 74.4 & 74.00 \\
\hline 8 & 5 & 30 & 200 & 1.25 & 73.67 & 74.06 \\
\hline 9 & 4 & 30 & 150 & 0.75 & 70.16 & 69.27 \\
\hline 10 & 6 & 30 & 150 & 0.75 & 64.48 & 65.04 \\
\hline 11 & 4 & 30 & 150 & 1.25 & 83.39 & 83.24 \\
\hline 12 & 6 & 30 & 150 & 1.25 & 69.93 & 71.23 \\
\hline 13 & 5 & 25 & 100 & 1 & 71.98 & 71.55 \\
\hline 14 & 5 & 35 & 100 & 1 & 70 & 68.84 \\
\hline 15 & 5 & 25 & 200 & 1 & 70.75 & 72.32 \\
\hline 16 & 5 & 35 & 200 & 1 & 67.89 & 68.74 \\
\hline 17 & 4 & 30 & 100 & 1 & 75.85 & 77.17 \\
\hline 18 & 6 & 30 & 100 & 1 & 65.78 & 66.94 \\
\hline 19 & 4 & 30 & 200 & 1 & 76.87 & 75.40 \\
\hline 20 & 6 & 30 & 200 & 1 & 71.01 & 69.38 \\
\hline 21 & 5 & 25 & 150 & 0.75 & 65.93 & 66.41 \\
\hline 22 & 5 & 35 & 150 & 0.75 & 64.1 & 64.18 \\
\hline 23 & 5 & 25 & 150 & 1.25 & 77.8 & 77.41 \\
\hline 24 & 5 & 35 & 150 & 1.25 & 74.13 & 73.34 \\
\hline 25 & 5 & 30 & 150 & 1 & 71.9 & 69.84 \\
\hline 26 & 5 & 30 & 150 & 1 & 69.55 & 69.84 \\
\hline 27 & 5 & 30 & 150 & 1 & 69.14 & 69.84 \\
\hline 28 & 5 & 30 & 150 & 1 & 69.33 & 69.84 \\
\hline 29 & 5 & 30 & 150 & 1 & 69.31 & 69.84 \\
\hline
\end{tabular}

Table 2 ANOVA for Amido black decolourization by enzyme

\begin{tabular}{|c|c|c|c|c|c|}
\hline Source & $\begin{array}{c}\text { Sum of } \\
\text { Squares }\end{array}$ & Df & $\begin{array}{c}\text { Mean } \\
\text { Square }\end{array}$ & $\begin{array}{c}\mathrm{F} \\
\text { Value }\end{array}$ & $\begin{array}{c}\mathrm{p} \text {-value } \\
\text { Prob }>\mathrm{F}\end{array}$ \\
\hline Model & 636.78 & 14 & 45.48 & 25.05 & $<0.0001^{*}$ \\
\hline Residual & 25.41 & 14 & 1.81 & & \\
\hline Lack of Fit & 20.05 & 10 & 2.00 & 1.496841 & 0.3714 \\
\hline Pure Error & 5.35 & 4 & 1.33 & & \\
\hline Cor Total & 662.20 & 28 & & \\
\hline \multicolumn{7}{|c|}{$\mathrm{R}^{2}-0.9616$} & Adj $\mathrm{R}^{2}-0.9232$ \\
\hline
\end{tabular}

* Significant at $95 \%$ confidence interval

Figure 2 (a) 2D contour plot showing factor interaction between $\mathrm{pH}$ and temperature (b) 2D contour plot showing factor interaction between $\mathrm{pH}$ and enzyme volume.

(a)

R1

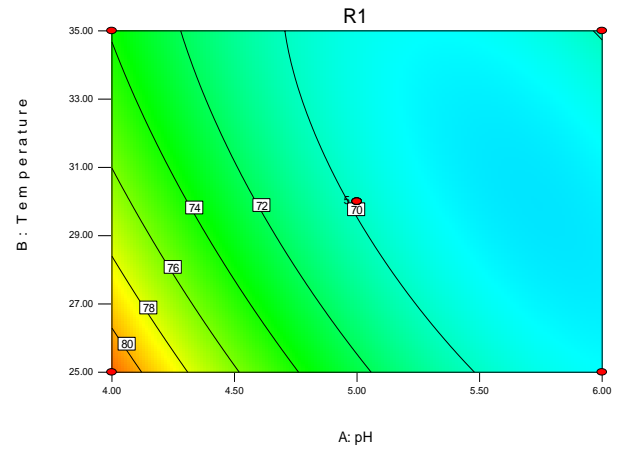

(b)

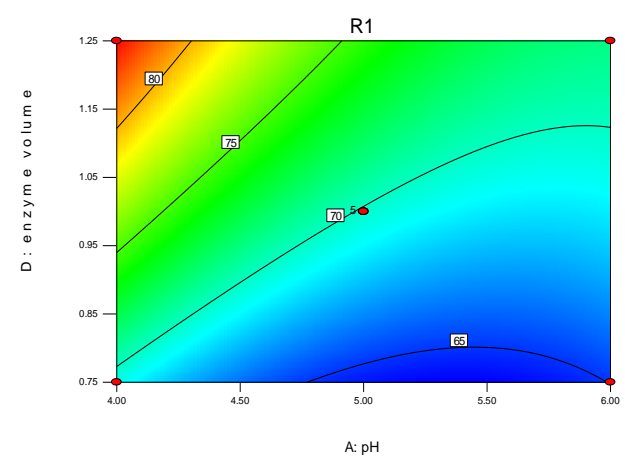




\section{Conclusion}

The laccase extracted from Rigidoporus ulmarius showed promising potential for decolourization of amido black. $83 \%$ decolourization was achieved by using the crude enzyme at $24 \mathrm{hrs}$ of incubation. The enzyme can be applied for low- purity applications like waste treatment. Further purification of the enzyme or induction of enzyme production can provide for complete decolorization solutions. Studies on the degradation pathway of the enzyme can provide an insight for application in treatment of wide range dyes and chemicals.

\section{Acknowledgements}

The authors would like to express their sincere gratitude to Dr.Jeppiaar, Chairman, Jeppiaar engineering college and Dr. Shaleesha A. Stanley, Head of the department, Department of Biotechnology, Jeppiaar engineering college for providing constant support to carry out this work in the laboratory.

\section{References}

[1] M.R. Oveisi, M. Hajimahmoodi, F. Davami, Simultaneous Spectrophotometric Determination of Mixtures of Food Colorants. Daru Journal of Pharmaceutical Sciences, 11(1), 2003, 1-6.

[2] S. Asad, M.A. Amoozegar, A.A. Pourbabaee, M.N. Sarbolouki, S.M.M. Dastgheib, Decolorization of Textile Azo Dyes by Newly Isolated Halophilic and Halotolerant Bacteria. Bioresource Technology, 98(11), 2007, 2082-2088.

[3] Y. Suzuki, T. Yoda, A. Ruhul and W. Sugiura, Molecular cloning and characterization of the gene coding for azoreductase from Bacillus sp. OY1-2 isolated from soil'. Journal of Biological Chemistry, 276(12), 2001, 9059-9065.

[4] D. Wesenberg, I. Kyriakides, S.N. Agathos, White-Rot Fungi and Their Enzymes for the Treatment of Industrial Dye Effluents. Biotechnology Advances, 22(1-2), 2003, 161-187.

[5] A.B. Dos Santos, F.J. Cervantes, J.B.V. Lier, Review Paper on Current Technologies for Decolourisation of Textile Wastewater: Perspectives for Anaerobic Biotechnology. Bioresource Technology, 98(12), 2007, 2369-2385.

[6] R.G. Saratale, G.D. Saratale, J.S. Chang, S.P. Govindwar, Bacterial decolorization and degradation of azo dyes: A review. Journal of the Taiwan Institute of Chemical Engineers, 42(1), 2011, 138-157.

[7] T. Robinson, G. McMullan, R. Marchant, P. Nigam, Remediation of dyes in textile effluents: a critical review on current treatment technologies with a proposed alternative. Bioresource Technology, 77(3), 2001, 247-255.

[8] P. Baldrian, Fungal laccases occurrence and properties. FEMS Microbiology Reviews, 30(2), $2006,215-242$.

[9] H. Forootanfar, M.M. Movahednia, S. Yaghmaei, M. Tabatabaei-Sameni, H. Rastegar, A. Sadighi, M.A. Faramarzi, Removal of chlorophenolic derivatives by soil isolated ascomycete of Paraconiothyrium variabile and studying the role of its extracellular laccase. Journal of Hazardous Materials, 209-210, 2012, 199-203.

[10] E.M. Giorgio, M.I. Fonseca, M.R. Tejerina, A.B. Ramos-Hryb, N. Sanabria, P.D. Zapata, L.L. Villalba, Chips and Sawdust Substrates Application for Lignocellulolytic Enzymes Production by Solid State Fermentation. International Research Journal of Biotechnology, 3(7), 2012, 120-127.

[11] M. Krishnaveni and R. Kowsalya, Characterization and Decolorization of Dye and Textile Effluent by Laccase from Pleurotus floridaA White-Rot Fungi. International Journal of Pharma and Bio Sciences, 2(1), 2011, 117-123.

[12] Savitha S. Desai, Gururaj B. Tennali, Nityanand Channur, A.C. Anup , Gouri Deshpande, B.P. Azhar Murtuza, Isolation of Laccase Producing Fungi and Partial Characterization of Laccase. Biotechnology, Bioinformatics and Bioengineering, 1(4), 2011, 543-549.

[13] S Arul Diana Christie and S Shanmugam, Analysis of Fungal Cultures Isolated from Anamalai Hills for Laccase Enzyme Production Effect on Dye Decolorization, Antimicrobial Activity. International Journal of Plant, Animal and Environmental Sciences, 2(3), 2012, 143-148.

[14] A Jhadav, K.K. Vamsi, Y. Khairnar, A. Boraste, N. Gupta, S. Trivedi, P. Patil, G. Gupta, M. Gupta, A.K. Mujapara, B. Joshi, D. Mishra, Optimization of Production and Partial Purification of Laccase by Phanerochaete chrysosporium Using Submerged Fermentation. International Journal of Microbiology Research, 1(2), 2009, 09-12.

[15] R. Satar, Q. Husain, Catalyzed Degradation of Disperse Dyes by Calcium Alginate-Pectin Entrapped Bitter Gourd (Momordica charantia) Peroxidase. Journal of Environmental Sciences, 23(7), 2011, 1135-1142.

[16] A.B.M.S. Roriz, J.F. Osmaa, J.A. Teixeirab, S.R. Couto, Application of Response Surface Methodological Approach to Optimise Reactive Black 5 Decolouration by Crude Laccase from Trametes pubescens. Journal of Hazardous Materials, 169(1-3), 2009, 691696.

[17] M. Lorenzo, D. Moldes, Sanroman Ma, Effect of Heavy Metals on the Production of Several Laccase Isoenzymes by Trametes versicolor and on Their Ability to Decolourise Dyes. Chemosphere, 63(6), 2006, 912-917.

[18] N. Bari, Z. Alam, S.A. Muyibi, P. Jamal and Abdullah-Al- Mamun, Statistical optimization of process parameters for the production of citric acid from oil palm empty fruit bunches. African Journal of Biotechnology, 9 (4), 2010, 554-563.

[19] P. Kumar, T. Satyanarayana, Optimization of culture variables for improving glucoamylase production by alginate-entrapped Thermomucor indicaeseudaticae using statistical methods. Bioresource technology 98 (6), 2007, 1252-1259.

[20] Z.W. Wang and X.L. Liu,Medium optimization for antifungal active substances production from a newly isolated Paenibacillus sp. using response surface methodology. Bioresource Technology, 99(17), 2008, 8245-8251. 